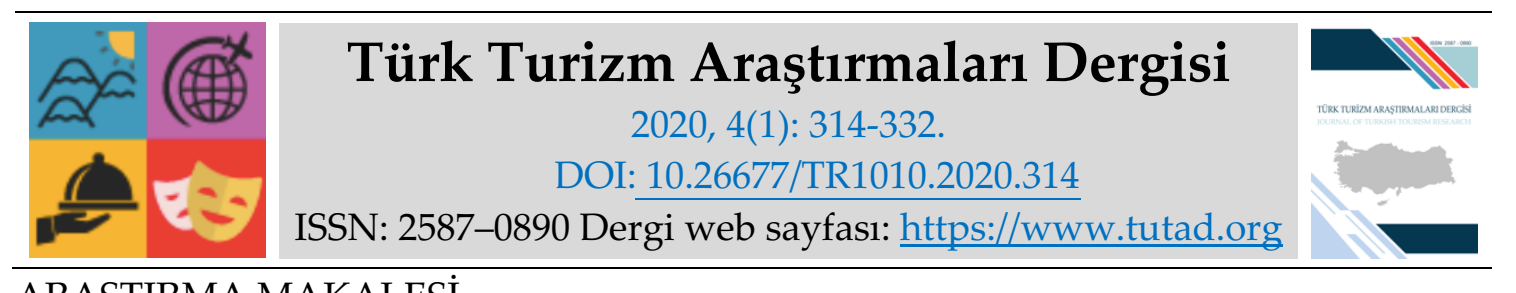

ARAŞTIRMA MAKALESI

\title{
Gençlik Turizmine Üniversiteli Gençlerin Bakış Açısı: Doğu Akdeniz ile Kocaeli Üniversitesi Karşılaştırılması
}

İrem KARATAŞ, Doğu Akdeniz Üniversitesi, Turizm Fakültesi, Kuzey Kıbrıs Türk Cumhuriyeti, eposta: iremkaratas05@gmail.com

ORCID: https://orcid.org/0000-0002-5962-0306

Dr. Öğr. Üyesi Özlem ALTUN, Kıbrıs Sosyal Bilimler Üniversitesi, İnsan ve Toplum Bilimleri Fakültesi, Kuzey Kıbrıs Türk Cumhuriyeti, e-posta: ozlem.altun@kisbu.edu.tr

ORCID: https://orcid.org/0000-0002-0830-002X

Dr. Mehmet Necati CIZRELIOĞULLARI, Kıbrıs Batı Üniversitesi, İktisadi, İdari ve Sosyal Bilimler Fakültesi, Kuzey Kıbrıs Türk Cumhuriyeti, e-posta: cizrelioglu.necati@gmail.com

ORCID: https://orcid.org/0000-0002-9884-6084

Öz

Turizm insanların bir yerden başka bir yere seyahat etmesi ile başlayan ancak bireylerin tercih ve imkanları dahilinde gerçekleşmesi ile farklılık gösteren bir eylem türüdür, küreselleşen dünyada bu imkanlar günden gün değişmektedir. Bu değişim, gençlerin sosyal yapısı, refah düzeyi, kendi tercihleri ve en önemlisi isteklerini ve meraklarını belirleyerek özel ilgi turizm türlerinden gençlik turizmin ortaya çıkmasına zemin hazırlamıştır. Çalışmanın amacı, Doğu Akdeniz Üniversitesi ve Kocaeli Üniversitesinde okuyan 18-25 yaş aralı̆̆ındaki öğrencilerin gençlik turizmi'ne bakış açısını incelemek ve gençlerin tercihlerini etkileyen faktörleri belirlemektir. Genç bireylerin, seyahat esnasında ve öncesinde beklenti ve tutumların belirleyip hangi faktörlerin etkili olduğunu objektif olarak değerlendirmek için Doğu Akdeniz ve Kocaeli Üniversitesinde okuyan 283 kişi üzerinde anket çalışması yapılmıştır. Araştırmanın sonucunda, cinsiyet değişkeninin üniversite öğrencilerin gençlik turizme bakış ve tutumlarına doğrudan etki etmediği kanısına varılmıştır. Bunun yanında, Doğu Akdeniz ve Kocaeli Üniversitesinde okuyan gençlerin, gençlik turizme hem ekonomik hemde güven değişkenleri açısından dolaylı olarak etki bıraktığı görülmüştür. Genç turistlerin gençlik turizme bakışını etkileyen faktörlerin kapsamlı tespitleri yapılabilmesi için bu çalışma ileride yapılması planlanan çalışmalara katkı sunacaktır.

Anahtar Kelimeler: Turizm, Özel İlgi Turizmi, Üniversite Öğrencileri, Gençlik Turizm.

Makale Gönderme Tarihi: 07.10.2019

Makale Kabul Tarihi: 13.01 .2020

Önerilen Atıf:

Karataş, İ., Altun, Ö. ve Cizrelioğulları, M. N. (2020). Gençlik Turizmine Üniversiteli Gençlerin Bakış Açısı: Doğu Akdeniz ile Kocaeli Üniversitesi Karşılaştırılması, Türk Turizm Araştırmaları Dergisi, 4(1): 314-332.

(C) 2020 Türk Turizm Araştırmaları Dergisi. 


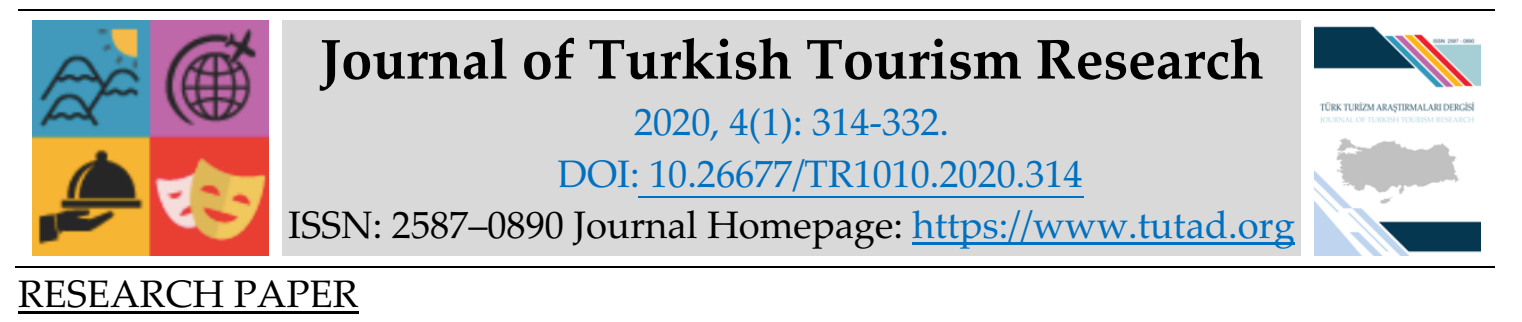

\section{The Point of View of Youth in Youth Tourism: Comparison of Eastern Mediterranean University and Kocaeli University}

İrem KARATAŞ, Doğu Akdeniz University, Faculty of Tourism, Turkish Republic of Northern Cyprus, e-mail: iremkaratas05@gmail.com

ORCID: https://orcid.org/0000-0002-5962-0306

Asst. Prof. Dr. Özlem ALTUN, Cyprus University of Social Sciences, Faculty of Humanities and Social Sciences, Turkish Republic of Northern Cyprus, e-mail: ozlem.altun@kisbu.edu.tr

ORCID: https://orcid.org/0000-0002-0830-002X

Dr. Mehmet Necati CIZRELIOĞULLARI, Cyprus Western University, Faculty of Economics, Administrative and Social Sciences, Turkish Republic of Northern Cyprus, e-mail: cizrelioglu.necati@gmail.com

ORCID: https://orcid.org/0000-0002-9884-6084

\section{Abstract}

Tourism is a type of action in which individuals begin with traveling from one place to another and perform in accordance with their preferences and possibilities. These opportunities are changing day by day in the globalized world. This change has determined the social structure of young people, their welfare level, their preferences and most importantly their wishes and curiosities and prepared the ground for the emergence of youth tourism. The aim of this study is to examine the perspectives of 18-25-year-old students studying at Eastern Mediterranean University and Kocaeli University on youth tourism and to determine the factors affecting the preferences of young people. A survey was conducted on 283 people studying at Eastern Mediterranean and Kocaeli University in order to determine the expectations and attitudes of young individuals before and during travel and to evaluate the factors which are effective. As a result of the study, it was concluded that the gender variable did not have a direct effect on university students' attitude and view towards youth tourism. In addition, it is seen that young people studying at Eastern Mediterranean and Kocaeli University indirectly affect youth tourism in terms of both economic and trust variables. This study will contribute to the future studies in order to make a comprehensive determination of the factors that affect young tourists' view of youth tourism.

Keywords: Tourism, Special Interest Tourism, University Students, Youth Tourism.

Received: 07.10.2019

Accepted: 13.01 .2020

\section{Suggested Citation:}

Karataş, İ., Altun, Ö. and Cizrelioğulları, M. N. (2020). The Point of View of Youth in Youth Tourism: Comparison of Eastern Mediterranean University and Kocaeli University, Journal of Turkish Tourism Research, 4(1): 314-332.

() 2020 Türk Turizm Araştırmaları Dergisi. 


\section{GíRiş}

Günümüzde turizm mevsimsellikten çıkmış ve tüm yıla yayılmıştır. Buna bağlı olarak çok çeşitli ve farklı alanlarda insanların ilgi, yetenek ve meraklarına hitap eden özel ilgi turizmi ortaya çıkmıştır. Tam olarak sayısını belirtmek pek mümkün olmasa da Golf, Uzay, Hüzün, Gastronomi, Festival ve Fuarlar, İnanç ve Gençlik Turizmi gibi özel ilgi turizm çeşitlerine örnek verilebilir (Akinci ve Kasalak, 2016). Gençlik Turizminde, yapılan seyahatlar 18-25 yaş aralığındaki bireylerin düşünce ve tutumları doğrultusunda değişmektedir. Bu turizm çeşidi gelir düzeyi yüksek bir kesime hitap eden özel ilgi turizm çeşitlerinden bir tanesidir. Gençlik turizmi genellikle sırt çantası ile yapılan daha rahat bir seyahat anlamına gelmektedir. Asıl amacı en ekonomik şekilde en güzel ve en uzun süreli tatili gerçekleştirmek olarak tanımlanabilir (Öztürk ve Yazıcıoğlu, 2002; Köroğlu ve Güleç, 2008). Gençlik turizmi 18-25 yaş arasındaki (okuyup okumayan gözetmeksizin) genç bireylerin seyahatini kapsamaktadır (Küçükaltan, 1995; Richards ve Wilson, 2006). Seyahatlerin kapsamında yapılan gençlik festivalleri, dil eğitimleri ve Gençlik ve Spor Bakanlıkları kapsamında yapılan faaliyetler de oluşturmaktadır. Gençlik turizmi, daha çok kendi kendini finanse eden genç bireylerin tercih ettiği ve günden güne gelişim göstermekte olan bir turizm çeşididir. Gençleri seyahate teşvik etmek için bakanlıkların yapmış olduğu kurum ve kuruluşların oluşturduğu projelerin destek ve teşvik hibeleri, her kesime hitap etmekle beraber kolaylık sağlamaktadır (TÜRSAB, 2015). Türkiye'de pek fazla bu tür projeler gerektiği kadar ses getirmese de Avrupa ülkelerinde bu projelerin daha etkili olduğu görülmektedir. Bu tür seyahatler olmadı̆̆ında bile, devlet gözetiminde sanata ve sanatçıya değer veren genç bireylerden oluşan topluluklar gençlik turizmin önemini oluşturmaktadır (Köroğlu ve Güleç, 2008). Tabi ki de bu tür projeleri yaparken ülkenin sosyal kültür seviyesini de dikkate almak gerekmektedir. Ailelerin refah düzeyi ne kadar iyi olursa ve kültür düzeyi ne kadar geniş olursa çocukları da bir o kadar özgür düşünebilen ve özgüveni yüksek olan bireyler olabilmektedir (Khoshpakyants ve Vidishcheva, 2010).

Genç bireylerin seyahatlerinin temelinde, yaşadıkları çevrenin dışında kalan zamanda çevreyi tanıyıp oralarda yaşayan insanların yaşama şekillerini görmek yeni deneyimler kazanmak vardır (Polat, 2017). Bireyler, yeni kültürler ile tanışıp onların doğru ve yanlışını ayırt ederek, tatil süresi boyunca o kültüre adapte olabilmektedir. Genç bireylerin bu tür farklılıklarına ne kadar kolay adapte olup olmamaları gelecekte iş alanında yaşanacak değişikliklere gösterecekleri davranışların temelini de oluşturmaktadır. Bu bağlamda, gençlik turizimin tercih sebebi daha çok gençlerin merak duygusu ile orantılı bir şekilde oluşmaktadır (Öztürk ve Yazıcığlu, 2002; Tezcan vd., 2018). Özellikle, deneyim kazanmak isteyen ve uzun mesafeli seyahat eden gençler için bu seyahatlerin özbenlik gelişimlerini olumlu etkilediği görülmektedir (Richards ve Wilson, 2006). Gençlik turizmi, gençlerin hür düşüncesini siyasal, ekonomik hukuki ve doğal çevreyi serbestçe değerlendirme kapasitesini geliştiren, gençlere farklı ülkeleri ve insanları sevmesini öğreten bir olgudur. Gençlik turizmi, gençlerin karşılaştırma yapma gücünü ve bilgilerini artırır ve kötü alışkanlıklardan uzak durmalarını sağlar. Gençlere kazandırdığı kişisel faydaların yanı sıra, ülkelerin diş tanıtımı ve turizm işletmelerinin rantabilitesini artıran bir turizm çeşidi olarak da önem arz etmektedir (Oral, 1992; Kaşlı vd., 2013).

Genç bireylerin okudukları bölümün ağırlığından ya da hafifliğinden kaynaklanan tatil programindan beklentileri değişmektedir. Bunu en temel örneği turizm fakültesinde okuyan bir birey ile hukuk fakültesinde okuyan bir bireyin yapacağı tatil araştırmaları ve seçimleri farklılık göstermesidir (Şahin vd., 2018). Mevcut çalışmanın amacı, Doğu Akdeniz Üniversitesi ve Kocaeli Üniversitesin'de okuyan öğrencilerin gençlik turizmi'ne bakış açısını incelemek ve gençlerin 
tercihlerini etkileyen faktörleri belirlemektir. Özel ilgi turizmin bir çeşidi olan gençlik turizmi türünün farkındalığı yaklaşık olarak son on yılda artış göstermiş olup günümüzde tatil programları ve kampanyalar bu doğrultuda yapılmaya başlanmasından dolayı bu çalışmanın yapılması önem kazanmıştır.

\section{KAVRAMSAL ÇERÇEVE}

İnsanlar ilk var oldukları zamanlardan, günümüze gelene kadar hep bir hareket halindelerdir. Bu hareketlilikleri kendi varlıklarını ilerletebilmek ve aklımıza getirebilecek her şeyin yenisini keşvedip bir ileriye taşımak için yapmışlardır (Carr, 2002). Her ne kadar insanlar sebep olarak avlanmak için mağaralarından dışarıya çıksalar da her bir arayış beraberinde yeni destinasyonları getirmiştir. Bu destinasyon arayışları ilk etapta iklim koşullarına uyum sağlayamamaktan, bulundukları yerin coğrafi özellik problemlerinden ve benzeri durumlardan kaynaklanması göç olgusunu meydana getirmiştir (Özdemir ve Kervankıran, 2011; Gülbahar, 2009). Fakat her göç aslında keşvedilen yeni bir destinasyon olma anlamına gelmektedir. Bu destinasyonlar her gün geçtikte nüfusun artmasıyla da sıklık göstermeye başlamıştır. İnsanlar artık bir yerlere yerleşip evlerini kurduktan sonra bu hareketlilik keyif almak için oluşturmaya başlamıştır. Keyif almak için olan hareketlilik, günümüzde turizminin şekillenmesinin başlamasına zemin oluşturmuştur (Beşirli, 2010; Kozak vd., 2013). Öncelikle insanlar yeni yerleşimlerinde, keşif yaparak sadece küçük bohça şeklinde yaşamlarını idare edecek kadar yemekler ve av malzemeleri ile yapmışlardır. Bu zaman geçtikçe yeni taşıma aletleri keşvedildikçe yanlarında getirip götürdükleri eşylarda şekillenmeye başlamıştır (Zoğal ve Emekli, 2017). Yakın tarihlere bakıldığında, insanlar başka bölgelerde yaşayan tanıdıklarını ziyaret amacı ile gidip onlarda birkaç gün konaklayıp tekrar kendi evlerine dönmeye başlaması ile birlikte daha fazla eşya ile konaklamalar yapmaya başlamıştır (Beşirli, 2010; Tümertekin ve Özgüç, 2011). Zaman değiştikçe ve yeni iş sahaları ortaya çıkmaya başlamasıyla, şehir merkezi ve köy denilen kavramlar ortaya çıkmaya başlamıştır. Beraberinde insanların iş sebepli seyahatleri oluşmuştur. Çalışma hayatına başlayan insanların refah düzeyleri arttıkça, istek ve arzularıda değişmeye başlamıştır. Maddi olanağı olan insanlar artık otellerde kalmaya ve seyahat etmeye başlamışlardır. Maddi olanağı olmayanlar akrabalarında konaklamalı seyahatlere devam etmiştir. Ülke ekonomisi geliştikçe insanlarda turizmi algisı ve düşüncesi de bir o kadar gelişmiş, değişik turizim faaliyetlerin ortaya çıkmıştır (Öztürk ve Yazıcıoğlu, 2002). Ortaya çıkan yenilikler turizm alanında yeni kavramlar türetmeye başlamıştır. En temel kavram olarak seyahat eden kişilere turist denilmeye başlanmıştır. Turistler yerli ve yabancı olarak ayrışmaya başlanmıştır. Kavramlar çoğaldıkça, yeni otel terminolojileri ve hizmetleri sunulmuştur. Günümüzde teknolojinin de gelişimi ile her şey yön değiştirmeye başlamıştır, Turizm alanında ki klasik kavramlar her geçen gün gelişerek değişmiştir (Yıldız ve Yıldız, 2015). Kısacası, insanlar artık temel turizmi algısı olan deniz, kum, güneş (3S) olarak düşünmüyor. Genel olarak turizmin tanımı olan bir yerden bir yere seyehat etmek olarak tabir edilmektedir (Albayrak ve Özmen, 2018). Fakat değişen günümüz şartları ile turistlerinde refah düzeyleri değişmiştir. Bu değişimleri, insanların seyahat için tercih ettikleri yerlerde etkilemeye başlamıştır. Bu bağlamda, bu insanlar hiç görülmemiş yerleri görmek, hiç deneyimlemedikleri duyguları yaşamak, hiç yemedikleri yemekleri yemek gibi ihtiyaçların doğması çeşitli turizm faaliyetlerin ortaya çıkmasına zemin hazırlamıştır (Duran, 2011; Uygur ve Baykan, 2007). Bunun yanı sıra tanımadıkları insanlar ile tanışıp kendilerine yeni arkadaşlar edinmek istemeleri ve bu isteklerinin sonucu olarak özel ilgi turizm çeşitleri ortaya çıkmıştır. Özel ilgi turizm, turistlerin kendi düşünce ve yaşayış şekillerine göre şekillenmektedir. Dış çevre kendi düşünce ve yaşayış şekillerini 
etkileyen etmenlerdendir. Dış çevre olarak kişilerin eşi-dostu, seçmiş olduğu meslek, aldiğı maaş, yaşadığı şehir, sahip olduğu mal mülk olmakla beraber daha bir sürü şeyi içinde barındırmaktadır. İnsanlar daha çok bunlara bağlı kalarak daha önce deneyimlemedikleri şeyleri tercih etmektedirler (Öztürk ve Yazıcıŏ̆lu, 2002; Kılıç ve Kurnaz, 2010).

Günümüz teknolojisi ile gelişen sosyal medya da, insanların içlerindeki süper egoyu uyandırarak onların toplum içerisinde daha çok söz sahibi olmayı ve popülerliği getirmektedir. Bu etmenlerin hepsi bir araya gelince ve ilk insanların mağaradan sedece yemek arayışına çıkmak için seyahat ettiklerini düşünceside turizmin aslında bir bebek gibi büyüyüp geliştiğini ve bir çok şeye etkisi olduğunu görebiliyoruz (Bizirgiannia ve Dionysopouloub, 2013; Eryılmaz ve Zengin, 2014). Özel ilgi turizmi, sadece zenginlerin yaptığı turizm ve çokça maliyet gerektiren bir alt başlık olmaktan çıkmaktadır (Akıncı ve Kasalak, 2016). Önemli özel ilgi turizm çeşitlerinden biri olan gençlik turizmi, daha az maliyet ile daha fazla yer gezip görme anlamına gelmektedir. Yurtdışında gençlerin hemen hemen her haftasonu büyük yeşillik bir alanda küçük festival sahneleri ve müzikli etkinlikler için çadırları kurulmaktadır. Bu gelişim gençlik turizmin ortaya çıkmasına neden olmuştur (Sellars, 1998).

Genç bireylerin toplumlar arasında kültürel farklılı̆̆ı, diğer bireylere göre daha rahat karşılayabiliyor ve saygı duyabiliyorlar. Toplumdaki farklılıklar ile onların dışlanmadan daha uyumlu bir şekilde yaşam sürdürmesini sağlamaktadır. İnsanlar kültürler arası köprü görevindedir fakat bu köprüyü gençler daha rahat inşa edebilmektedir (Polat, 2017). Gençlik turizmi, genç bireylerin yeni insanlar ile tanışarak kendilerine yeni iş imkanları sağlamakla beraber sosyal imkanı el vermeyen insanların da önünü açmaktadır (Khoshpakyants ve Vidishcheva, 2010). Sosyal olarak toplum tarafından kabul görmeyen, ailevi problemleri olup sevgiye doymamış olan gençlerin duygu açlı̆̆ından suç işleme oranları daha fazladır. Gençlik turizmi ekonomik açıdan her kesimden genç bireye hitap ettiğinden dolayı hem gençlere hem de topluma bu açıdan olumlu katkı sağlamaktadır (Han vd., 2017). Gençler, ailelerinden bağımsız seyahat ettikleri zaman zorluklarla başa çıkmayı, kendi paralarını kontrol etmeyi öğrenmekte ve yeni yerler keşfetmektedirler (Bell, 2002). Heyecanlı ve benzersiz deneyimlerin, ucuz seyahat imkânlarıyla bir araya gelmesi gençleri turizme iten önemli bir nedendir. Bunların yanı sıra yabancı dil öğrenme ve farklı bir kültürü tanıma gibi iş bulma konusunda üstünlük sağlayacak özellikler de gençlik turizmin öneminin kazanmasına neden olmaktadır (Ghețe, 2015).

Ekonomik olarak genç bireylerin en çok zorlandıkları durumlardan birisi Türk lirasının değersiz olmasıdır. Devamında ise, kalacak yerlerin pahalılığı, ucuz olan yerlerin ise eksik bilgilendirme ile daha sonrasında ek ücretlerin ortaya çıkması, vize ücretleri ve bunu takiben harç pulu ücretleri gelmektedir. Gidilen yerlerde yerel ürünlerin pahalılığı, fakat bunların en temelinde yer alan problemler gençlerin kendilerine finansal anlamda kaynak bulmakta zorlanmasıdır (Şahin ve Dinçer, 2016). Temel olarak, bu tür problemlerin başında siyaset unsuru yer almaktadır. Çünkü ülkelerin uyguladıkları siyasi oyunlar ülkelerde gerçekleşen ve gerçekleşmekte olan turizm hareketlerini direkt olarak etkilemektedir. Bunlarla beraber, Türkiye vatandaşı olan genç bireylerin temel problemlerinin başlıca sorunu, $\mathrm{AB}$ vatandaşı olunmamasından kaynaklanan vize alma konusunda yaşanan problemlerdir. Buna bağlı olarak bizim ülkemizde eğitimde yabancı dile verilen değerin yetersizliğide başlıca sorun haline gelmektedir (Acır, 2010, Horak ve Weber, 2000). Gençlik turizmin temelinde, bireylerin merak duygusuyla hareket etmeyi oluşturması düşüncesi yatmasına rağmen, bireylerin dünyanın ortak dili olan ingilizceyi tam anlayabilecek şekilde konuşamadıklarından soru sorma konusunda problemler yaşamaktadırlar. Bu durum, bireylerin yaşadıkları önyargının artmasına sebep olmaktadır (Bahar, 2016; Kozak vd., 2015). Fakat bunlardan bağımsız bir şekilde 
yaşanan problemler arasında bireylere karşı sözlü, fiili her türlü taciz, bireylerin sosyal olarak yaşadıkları sorunlar arasında yer almaktadır. Bu durum, gidilen ülkeye, bölgeye ve o bölgede yaşıyan insanlara bağlı olarak değişmektedir (Gürbüz, 2002; Bahar, 2016).

Gençlik turizmi, ülkemizde 1950 ve 1960 'lı yıllarda gelişim göstermeye başlamıştır. Gençlik turiziminin gelişiminin sürdürülmesi için komşu ülkelerle birlikte gençlik düzeyindeki ilişkiler başlamıştır. Bu dönemde de en önemli unsur yurtdışına çıkmak ya da ülke içinde çıkılan seyahatin öğrenciler için özel ücretlendirme içermesidir. Gençlik turizmi ve eğitim birbiri ile bağlantılı bir hal almaya başlamıştır. Çünkü bir şeyler yapmak için çabalayan genç bireylere saygı duyularak onların önünü açmak için yenilikler getirilmiş, günümüzdeki erasmus, exchange vb. programlar ortaya çıkmaya sebep olmuştur (Küçükaltan,1995). Günümüzde, Türkiye'de gerçekleştirilen 68,4 milyon yurt içi seyahat hareketinin yaklaşık yüzde 25'ini 7-25 yaş arası gençler oluşturmaktadır (TÜRSAB, 2015). Bu oran hafife alınmayacak kadar yüksek bir oran ve her gençin ekonomik durumu eşit olmaması dikkate alınmasıda gençlik turizmin önemini göstermektedir. Gençlik ve Spor Bakanlığının bünyesinde hazırlanan projeler kapsamında katılmak isteyen genç bireylere belirli bir miktarda hibe verilerek gençlik turizmine destek olunmasını teşvik etmektedir. Bu projeler Avrupa Birliğine girme sürecinde gerekli koşulları içermesinden dolayı başta güvenlik konusunda olmakla beraber her bir konuda ince elenip sık dokunulmaktadır (Smith, 1992; Horak ve Weber, 2000). Türkiye'deki gençlik turizmi sadece bakanlığa bağlı olarak gelişmemektedir. Genç bireylere yönelik yapılan festivaller içerisinde kamp ve müzik barındıran konserler gerçekleştirilmesi ve bağlı oldukları belediyelerde o bölgedeki genç bireyler için etkinlikler düzenlenmesi gençlik turizm faaliyetlerinden biridir. Genellikle bu etkinliklerde ve festivallerde geceleri konserler yapılmakta, gündüzleri ise gençlerin gezip tozmalarına müsade edilecek şekilde organize edilmektedir. Bu tür etkinlikler, sosyal medyanın sıklıkla kullanılmasına bağlı kalarak gençler aralarında birbirlerine kolaylıkla duyurabilmesi açısından kolay bir şekilde yayılmaktadır (Kozak vd., 2015).

\section{Araştırmanın Amacı}

Genç bireylerin yapacakları tatil planlarında zorlandıkları konuların başında para veya finansman bulmak ve ulaşım kolaylığı ve güven gelmektedir. Daha sonrasında kendilerine uygun tatil programı bulmak ve ne tür etkinlikleri istediklerine karar vermek kalmaktadır. Bu çalışmada, Doğu Akdeniz Üniversitesi ve Kocaeli Üniversitesinde okuyan öğrencilerin, gençlik turizmine bakış açısını okumuş oldukları bölümler dikkate alınarak, turizme etkilerinin belirlenmesi hedeflenmiştir. Bu bağlamda; bu çalışma, Doğu Akdeniz ve Kocaeli Üniversitesin de okuyan öğrencilerin tatil programı yaparken ki tutumlarını ekonomik, konaklama, ulaşım ve güvenlik faktörleri tercihlerini nasıl etkilemektedir sorusuna cevap aramaktadır. Başka bir perspektiften bakıldığında, özel okulda okuyan ile devlet okulunda okuyan bir bireyin yapacakları tatil programında hangi faktörlerin ne derece önemli olduğu ve buna bağlı kalarak cinsiyet ile gençlik turizmin değişkeni arasındaki ilişki incelenecektir.

\section{YÖNTEM}

Gençlik turizmi bünyesinde 18-25 yaş arasındaki genç bireylerin tümünü kapsamaktadır. Bu kapsam hiçbir maddi ve manevi farklılık gözetmeden bir gruba dahil edilmektedir. Fakat bireylerin gençlik turizmi kapsamında tercih ettikleri tatil programı, bireylerin kendi sosyal yapılarına göre, yaşadıkları bölgelere göre, maddi olanaklarına ve eğitim düzeylerine bağlı olarak değişiklik göstermetedir. 
Çalışmanın iki evreni bulunmaktadır. Birinci evren Doğu Akdeniz Üniversitesi (KKTC Gazimağusa), ikinci evreni ise Kocaeli Üniversitesi (Kocaeli)'dir. Bu çalışmada, anket çalışması yapılmış ve 5'li likert ölçeği kullanılmıştır. Anketler Kocaeli Üniversitesi ve Doğu Akdeniz Üniversitesinde okuyan "18-25 yaş aralığındaki bireylerin okudukları üniversitede seçtikleri bölümün, bireylerin yapacakları tatil programına olan etkisi nedir?" sorusuna cevap aranmıştır. Örneklem olarak, çalışma için en uygun olan aşamalı bir şekilde genelden özele doğru oluşturulmuş "alan örneklemesi yapılmıştır. Anket çalışması, 2 farklı üniversiteden, 6 farklı fakültede toplamda 350 kişi olarak hedeflenmiş ancak zaman ve maliyet kısıtlılığından dolayı 284 kişiye uygulanmıştır. Anket uygulanırken olasılıklı örnekleme yöntemlerinden, basit tesadüfi örnekleme yöntemi kullanılmıştır. Anket içeriğinde kişilerin tatil programı yaparken konaklama, ekonomik, ulaşım durumu ve bölge güvenliği bireyler için ne derece önemli olduğuna yönelik sorular sorulmuştur. Araştırma analizde, SPPS 22. ve AMOS 22. istatiksel programlardan yararlanılmıştır. Araştırmada, demoğrafik ve çok regrasyon analizi ile faktör analizlerinden açıklayıcı ve doğrulayıcı faktör analizi kullanılmıştır.

\section{BULGULAR}

Tablo 1'de görüldüğü üzere, Kocaeli ve K.K.T.C.' de toplam katılımcı sayısı 283 kişidir. Katılımcılardan 179 kişi Doğu Akdeniz Üniversitesi bağlı iken, 104 kişi Kocaeli Üniversitesine bağlıdır. KKTC'deki Doğu Akdeniz Üniversitesinde okuyan katılımcların çoğunu erkekler \%78.8 oluşturmaktadır. Kadın katılımcılar ise \%21.2 oluşturmuştur. Türkiye' deki Kocaeli Üniversitende ise katılımcıların çoğunu kadınlar \%80.8 oluşturmaktadır. Erkek katılımcı sayısı ise \%19.2 oluşturmuştur. Bundan başka, hem KKTC (109) hem de Kocaelinde (75) katılımcıların çoğu 21-23 yaş aralığında olduğu görülmektedir. Başka bir noktaya değindiğimizde, Doğu Akdeniz Üniversitesinde okuyan katılımcıların çoğu eğitim fakültesine bağlı iken (\%30.1), Kocaeli Üniversitesinde okuyan katılımcıların çoğu (\%43.3) ise mühendislik fakültesine kayıtlıdır. Buna ilaveten, Doğu Akdeniz Üniversitesinde okuyan katılımcıların en azını (\%5.0) hukuk fakültesi oluştururken, Kocaeli Üniversitesinde ise mimarlık ve eğitim fakültesine (\%4.8) kayıtlı öğrenciler oluşturmaktadır. Hukuk fakültesinde ise ankete katılan hiçbir öğrenci bulunmamıştır. 
Tablo 1. Demoğrafik Bulgular

\begin{tabular}{|c|c|c|c|c|c|}
\hline \multirow[t]{2}{*}{ Değişkenler } & & \multicolumn{2}{|c|}{ KKTC } & \multicolumn{2}{|c|}{ KOCAELI } \\
\hline & & $(\mathrm{N})$ & $\%$ & $(\mathrm{~N})$ & $\%$ \\
\hline \multirow[t]{2}{*}{ Cinsiyetiniz? } & Erkek & 141 & 78.8 & 20 & 19.2 \\
\hline & Kadın & 38 & 21.2 & 84 & 80.8 \\
\hline \multirow[t]{3}{*}{ Yaşınız? } & $18-20$ & 38 & 21.2 & 20 & 19.2 \\
\hline & $21-23$ & 109 & 57.5 & 75 & 72.1 \\
\hline & $24-27$ & 22 & 12.3 & 9 & 0.8 \\
\hline \multirow[t]{3}{*}{ Okulunuzun Adı } & Doğu Akdeniz & 179 & 100 & - & \\
\hline & Üniversitesi & & & & \\
\hline & Kocaeli Üniversitesi & - & & 104 & 100 \\
\hline \multirow[t]{6}{*}{ Okuduğunuz Fakülte } & Hukuk & 9 & 5.0 & - & \\
\hline & Sağlık & 47 & 26.3 & 40 & 38.4 \\
\hline & Eğitim & 54 & 30.1 & 5 & 4.8 \\
\hline & Mühendislik & 46 & 25.7 & 45 & 43.3 \\
\hline & Mimarlık & 13 & 7.3 & 5 & 4.8 \\
\hline & Fen ve Edebiyat & 10 & 5.6 & 9 & 8.7 \\
\hline \multirow[t]{2}{*}{ Anketin Yapıldı $\breve{g}_{1}$ Yer } & KKTC & 179 & 100 & - & - \\
\hline & Kocaeli & - & & 104 & 100 \\
\hline Toplam & & & & & \\
\hline
\end{tabular}

Tablo 2 gösterildiği üzere, çalışmada elde edilen verilerin geçerliliği açıklayıcı ve doğrulayıcı faktör analizi yapılarak incelenmiştir. Veri analizinin faktör yapısına uygun olup olmadığını saptamak amacıyla KMO (Kaiser-Meyer-Olkin) ve Bartlett"s testi yapılmıştır (Kaya ve Kaya, 2013). KKTC ekonomi KMO katsayısı 0.76, Kocaeli ekonomi KMO katsayısı 0.70 ve Bartlett testleri anlamlı çıkmıştır $(\mathrm{p}<0.05)$. Cronbach alfa değeri sırasıyla 0.85 ve 0,82 düzeyinde olması anketin güvenirliğinin kabul edilebilir olduğunu göstermektedir. Açıklayıcı faktör analizi (AFA) için KKTC ekonomi açıklanan toplam varyans \%45,907, Kocaeli ekonomi ise \%41.571 olarak bulunmuştur. Verilerin faktör yapısınının uyumlu düzeyde olması için tüm maddelerin 0,50 üzerinde bir faktör yüküne sahip olması gerektiğinden bu değerin altında olan maddeler analizden çıkarılmıştır. AFA analizinden sonra nihai uygulama neticesinde doğrulayıcı faktör analizi (DFA) saptanmıştır. Bu teknik, faktör analizi üzerine kurulu hipotezlerin ilişkileri belirleyen model ile elde edilen verinin hangi oranda uyuştuğu ayrıntılı bir şekilde istatiksel açıdan belirlemek için kullanılan bir tekniktir (Doğan ve Başokçu, 2010). Ekonomi ölçeğinin uyum istatiksellerini saptamak için Ki-kare, x²/sd, CFI, IFI, NFI VE RMSEA indexsleri kullanılmıştır. KKTC Ekonomi uyum istatiksellerinden $\mathrm{x}^{2} / \mathrm{sd}=3.556$ sonucu modelin kabul edilebilir olduğunu göstermektedir. NFI (0.90), CFI (0.92), IFI (0.92) değerlerinin iyi düzeyde olduğunu göstermektedir. Diğer bir açıdan incelendiğinde, Kocaeli ekonomi uyum istatiksellerinden $\mathrm{x}^{2} / \mathrm{sd}=1.409$, NFI (0.92), CFI (0.97) ve IFI (0.97) değerlerinin veri uyumu için normal ve iyi düzeyde olduğu görülmektedir. Model-veri uyumuna ilişkin değerler dikkate alındığında kurulan modelin veri uyumunun iyi olduğu görülmektedir. 
Farklı bir noktadan incelendiğinde, tablo 3' de KKTC konaklama ölçeğinin açıklanan varyansı \%53.227, Kocaeli konaklama'nın ise \%49.763 olarak görülmektedir. Cronbach alfa değerinin ise sırasıyla 0.87 ve 0,81 olarak belirlenmiştir. Konaklama ölçeğinin KMO testleri sırasıyla 0,67 ve 0,83 olarak saptanmıştır. Bu değerler, ölçeğin kabul edilebilir düzeyde olduğunu göstermektedir. Konaklama ölçeğinin uyum istatiksellerinden KKTC için x2/sd=3.797, Kocaeli için x2/sd=3.364 değerlerinin uyum indeksleri kabul edilebilir düzeydedir. Ayrıca, KKTC için NFI (0.89), CFI (0.92) ve IFI (0.92), Kocaeli için NFI (0.90), CFI (0.93) ve IFI (0.93) değerleri iyi ve kabul edilebilir indekslere sahip olduğu değerlerden anlaşılmaktadır.

Tablo 4' de görüldüğü üzere, KKTC ulaşım ölçeğinin açıklanan varyansı \%60.167, Kocaeli ulaşım'ın ise \%66.182 olarak belirlenmiştir. Cronbach alfa değerleri sırasıyla 0,83 ve 0,82 olarak, KMO testleri ise 0.83 ve 0.63 olarak saptanmıştır. Bu değerler kabul edilebilir düzeydedir. Bundan başka, KKTC ulaşım ölçeği x2/sd=2.697, Kocaeli ulaşım x2/sd=3.234 değerleri kabul edilebilir düzeydedir. Ayrıca, KKTC için NFI (0.95), CFI (0.97) ve IFI (0.97), Kocaeli için NFI (0.93), CFI (0.95) ve IFI (0.95) değerleri iyi ve kabul edilebilir uyum değerlerine sahip olduğu görülmektedir.

Son olarak, tablo 5'de güven ölçeği incelendiğinde, KKTC güven ölçeğinin açıklanan varyansı $\% 57.495$, Kocaelinin ise \%59.974 olarak görülmektedir. Cronbach alfa değerleri ise sirasıyla 0.85 ve 0.89 olarak, KMO testleri ise 0.71 ve 0.64 olarak berlirlenmiştir. Bu değerler kabul edilebilir düzeydedir. Faktör yükleme oranları 0.50 'dan az olan maddeler, araştırmanın daha belirgin olarak ortaya koyulabilmesi sebebiyle değerlendirme dişında tutulmuşlardır. Bunlara ilaveten, KKTC ulaşım model ölçeğinin uyum değeri indekslerinden $\mathrm{x}^{2} / \mathrm{sd}=4.208$, Kocaeli ulaşım $\mathrm{x}^{2} / \mathrm{sd}=3.829$ değerlerinin kabul edilebilir düzeyde olduğu görülmektedir. Doğrulayıcı faktör analizinin uyum değerlerinden KKTC güven için NFI (0.95), CFI (0.96) ve IFI (0.96), Kocaeli güven için NFI (0.92), CFI (0.96) ve IFI (0.96) değerlerine sahip olması modelin uyum değerlerinin iyi düzeyde olduğunu göstermektedir. 
Tablo 2. Ekonomi Değişkenlerinin Faktör Analizi

\begin{tabular}{|c|c|c|c|}
\hline \multicolumn{2}{|l|}{ KKTC Ekonomi } & AFA & DFA \\
\hline \multicolumn{2}{|c|}{ S3 Tatil organize ederken para birimine dikkat edilmelidir. } & 0.50 & 0.58 \\
\hline \multicolumn{2}{|c|}{$\begin{array}{l}\text { S6 Tatil planı yaparken yakın çevremizdeki insanların ev sahibi olduğu yerleri tercih } \\
\text { etmeliyiz. }\end{array}$} & 0.69 & 0.72 \\
\hline \multirow{2}{*}{\multicolumn{2}{|c|}{$\begin{array}{l}\text { S7 Otel seçerken şehir merkezinden uzak olmasına dikkat etmeliyiz. } \\
\text { S8 Tatil planı yaparken sadece bir kaynağa bağlı kalınmamalı ve bir kaç yerden fiyat } \\
\text { edinilmelidir. }\end{array}$}} & 0.63 & 0.68 \\
\hline & & 0.68 & 0.75 \\
\hline \multirow{2}{*}{\multicolumn{2}{|c|}{$\begin{array}{l}\text { S9 Tatil planı yaparken ilk önce bütçemizi organize etmeliyiz. } \\
\text { S10 Konaklamaya sonradan dahil olan vergilere dikkat etmeliyiz }\end{array}$}} & 0.79 & 0.86 \\
\hline & & 0.73 & 0.80 \\
\hline \multicolumn{2}{|r|}{ Açıklanan Varyans (\%) } & \multicolumn{2}{|c|}{45.907} \\
\hline AFA & $\begin{array}{l}\text { Total } \\
\text { Kaiser Mayer Olkin (KMO) test } \\
\text { Bartlett's Test of Sphericity }\end{array}$ & $\begin{array}{r}2 . \\
0 \\
X^{2}=3 \\
\end{array}$ & 979 \\
\hline DFA: Model uygunluk endeksleri & $\begin{array}{r}\text { Ki-Kare } \\
X^{2 / d f} \\
\text { NFI } \\
\text { CFI } \\
\text { IFI } \\
\text { RMSEA }\end{array}$ & & \\
\hline \multicolumn{2}{|l|}{ Güvenirlik Analizi } & \multicolumn{2}{|c|}{0.85} \\
\hline \multicolumn{2}{|l|}{ Kocaeli Ekonomi } & AFA & \\
\hline \multicolumn{2}{|c|}{$\begin{array}{l}\text { S5 Tatil planı organize ederken kalma süresini otelin gecelik ücretine gore } \\
\text { planlamalıyı. }\end{array}$} & 0.80 & 0.89 \\
\hline \multicolumn{2}{|c|}{$\begin{array}{l}\text { S6 Tatil planı yaparken yakın çevremizdeki insanların ev sahibi olduğu yerleri tercih } \\
\text { etmeliyiz }\end{array}$} & 0.71 & 0.77 \\
\hline \multirow{2}{*}{\multicolumn{2}{|c|}{$\begin{array}{l}\text { S7 Otel seçerken şehir merkezinden uzak olmasına dikkat etmeliyiz. } \\
\text { S8 Tatil planı yaparken sadece bir kaynağa bağlı kalınmamalı ve bir kaç yerden fiyat } \\
\text { edinilmelidir }\end{array}$}} & 0.84 & 0.91 \\
\hline & & 0.75 & 0.78 \\
\hline \multicolumn{2}{|c|}{ S9 Tatil planı yaparken ilk önce bütçemizi organize etmeliyiz } & 0.84 & 0.91 \\
\hline \multicolumn{2}{|c|}{ S10 Konaklamaya sonradan dahil olan vergilere dikkat etmeliyiz } & 0.77 & 0.80 \\
\hline \multirow{4}{*}{ AFA } & Açılanan Varyans (\%) & \multicolumn{2}{|c|}{41.571} \\
\hline & Total & \multicolumn{2}{|c|}{2.494} \\
\hline & Kaiser Mayer Olkin (KMO) test & \multicolumn{2}{|c|}{0.70} \\
\hline & Bartlett's Test of Sphericity & & \\
\hline & Ki-Kare & & \\
\hline & $\mathrm{X}^{2 / \mathrm{df}}$ & & \\
\hline DFA: Model uygunluk endeksleri & NFI & & \\
\hline & CFI & & \\
\hline & IFI & & \\
\hline & RMSEA & & \\
\hline Güvenirlik Analizi & Cronbach's Alpha & & \\
\hline
\end{tabular}


Tablo 3. Konaklama Değişkenlerinin Faktör Analizi

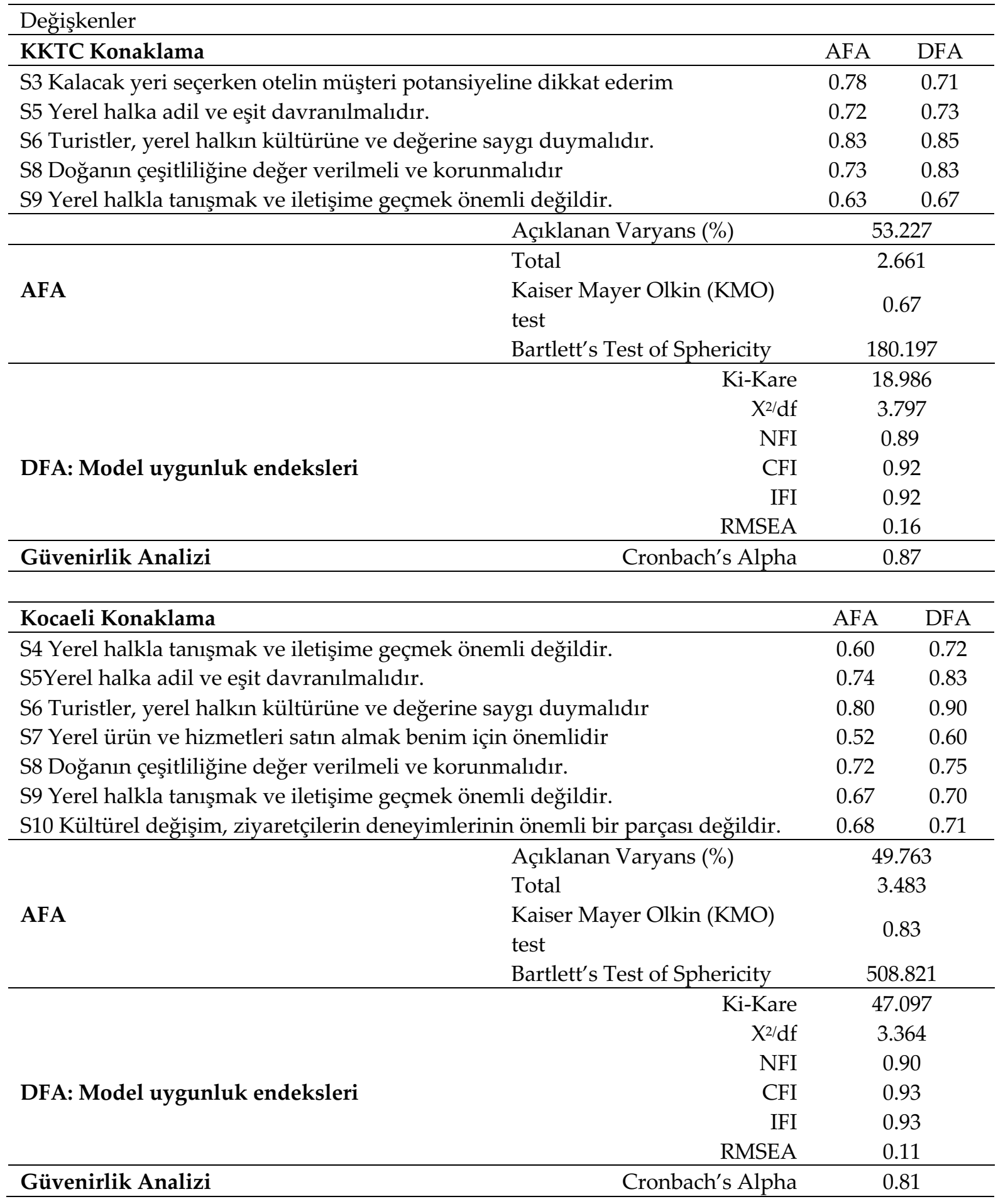


Tablo 4. Ulaşım Değişkenlerinin Faktör Analizi

\begin{tabular}{|c|c|c|c|}
\hline \multicolumn{4}{|l|}{ Değişkenler } \\
\hline \multicolumn{2}{|l|}{ KKTC Ulaşım } & AFA & DFA \\
\hline \multirow{2}{*}{\multicolumn{2}{|c|}{$\begin{array}{l}\text { S1 Tatil planı yaparken gideceğim yerlerin toplu taşıma imkanlarına dikkat ederim. } \\
\text { S2 Tatil için şehir planlarken o şehrin taksi fiyatlarına dikkat ederim. Örneğin önceden } \\
\text { google maps uygulamasından uber tarzı uygulamalardan kontrol ederim. }\end{array}$}} & 0.65 & 0.76 \\
\hline & & 0.65 & 0.76 \\
\hline \multicolumn{2}{|c|}{$\begin{array}{l}\text { S3 Otel seçimi yaparken, otelin yakınlarındaki otobüs duraklarının saatlerine ve otobüs } \\
\text { çeşitliliğine dikkat ederim }\end{array}$} & 0.55 & 0.67 \\
\hline \multicolumn{2}{|c|}{$\begin{array}{l}\text { S4 Gideceğim ülkelerde veya şehirlerde ulaşım için kart kullanılıyorsa satın almayı } \\
\text { tercih ederim. }\end{array}$} & 0.58 & 0.68 \\
\hline \multicolumn{2}{|c|}{ S5 Gideceğim yerler de ulaşımda öğrenci indirimi olup olmadığına dikkat ederim. } & 0.55 & 0.66 \\
\hline \multirow{4}{*}{ AFA } & Açıklanan Varyans (\%) & \multicolumn{2}{|c|}{60.167} \\
\hline & Total & \multicolumn{2}{|c|}{3.008} \\
\hline & Kaiser Mayer Olkin (KMO) test & \multicolumn{2}{|c|}{0.83} \\
\hline & Bartlett's Test of Sphericity & \multicolumn{2}{|c|}{313.220} \\
\hline \multirow{6}{*}{ DFA: Model uygunluk endeksleri } & Ki-Kare & \multicolumn{2}{|c|}{13.033} \\
\hline & $\mathrm{X}^{2 / \mathrm{df}}$ & \multicolumn{2}{|c|}{2.607} \\
\hline & NFI & \multicolumn{2}{|c|}{0.95} \\
\hline & CFI & \multicolumn{2}{|c|}{0.97} \\
\hline & IFI & \multicolumn{2}{|c|}{0.97} \\
\hline & RMSEA & \multicolumn{2}{|c|}{0.09} \\
\hline \multicolumn{2}{|l|}{ Güvenirlik Analizi } & \multicolumn{2}{|c|}{0.83} \\
\hline \multicolumn{2}{|l|}{ Kocaeli Ulaşım } & AFA & DFA \\
\hline \multicolumn{2}{|c|}{$\begin{array}{l}\text { S3 Otel seçimi yaparken, otelin yakınlarındaki otobüs duraklarının saatlerine ve otobüs } \\
\text { çeşitliliğine dikkat ederim }\end{array}$} & 0.61 & 0.62 \\
\hline \multicolumn{2}{|c|}{$\begin{array}{l}\text { S4 Gideceğim ülkelerde veya şehirlerde ulaşım için kart kullanılıyorsa satın almayı } \\
\text { tercih ederim. }\end{array}$} & 0.59 & 0.58 \\
\hline \multicolumn{2}{|c|}{ S5 Gideceğim yerler de ulaşımda öğrenci indirimi olup olmadığına dikkat ederim. } & 0.77 & 0.92 \\
\hline \multirow{4}{*}{ AFA } & Açıklanan Varyans (\%) & \multicolumn{2}{|c|}{66.182} \\
\hline & Total & \multicolumn{2}{|c|}{1.985} \\
\hline & Kaiser Mayer Olkin (KMO) test & \multicolumn{2}{|c|}{0.63} \\
\hline & Bartlett's Test of Sphericity & \multicolumn{2}{|c|}{76.166} \\
\hline \multirow{6}{*}{ DFA: Model uygunluk endeksleri } & Ki-Kare & \multicolumn{2}{|c|}{6.467} \\
\hline & $\mathrm{X}^{2 / \mathrm{df}}$ & & \\
\hline & NFI & & \\
\hline & CFI & & \\
\hline & IFI & & \\
\hline & RMSEA & & \\
\hline Güvenirlik Analizi & Cronbach's Alpha & & \\
\hline
\end{tabular}


Tablo 5. Güven Değişkenlerinin Faktör Analizi

\begin{tabular}{|c|c|c|c|}
\hline \multicolumn{4}{|l|}{ Değişkenler } \\
\hline \multicolumn{2}{|l|}{ KKTC Güven } & AFA & DFA \\
\hline & 0.53 & 0.65 \\
\hline \multicolumn{2}{|c|}{$\begin{array}{l}\text { S3 Gideceğim ülkenin siyasi politikasını incelerim ve turistlerin yasal korunma } \\
\text { haklarını okurum }\end{array}$} & 0.67 & 0.80 \\
\hline \multirow{2}{*}{\multicolumn{2}{|c|}{$\begin{array}{l}\text { S4 Ĕ̆er bir aracı şirket ile tatil programımı gerçekleştirmeye karar verdiysem o şirketin } \\
\text { eksizsiz olarak bütün lisanslarını ve sertifikalarını görmek isterim. } \\
\text { S5 Tercih edeceğiniz yerlerin gece güvenliği ile ilgilenirsiniz. }\end{array}$}} & 0.65 & 0.70 \\
\hline & & 0.51 & 0.59 \\
\hline AFA & $\begin{array}{l}\text { Açıklanan Varyans }(\%) \\
\text { Total } \\
\text { Kaiser Mayer Olkin (KMO) test } \\
\text { Bartlett's Test of Sphericity } \\
\end{array}$ & & $\begin{array}{l}195 \\
00 \\
194 \\
\end{array}$ \\
\hline DFA: Model uygunluk endeksleri & $\begin{array}{r}\text { Ki-Kare } \\
\mathrm{X}^{2 / \mathrm{df}} \\
\mathrm{NFI} \\
\mathrm{CFI} \\
\mathrm{IFI} \\
\text { RMSEA } \\
\end{array}$ & & $\begin{array}{l}16 \\
08 \\
95 \\
6 \\
6 \\
3 \\
\end{array}$ \\
\hline \multirow{2}{*}{\multicolumn{2}{|c|}{$\begin{array}{l}\text { Güvenirlik Analizi } \\
\text { Kocaeli Güven }\end{array}$}} & \multicolumn{2}{|c|}{0.85} \\
\hline & & AFA & DFA \\
\hline \multirow{3}{*}{\multicolumn{2}{|c|}{$\begin{array}{l}\text { S2 Gideceğim yere suç oranlarını araştırarak karar veririm. } \\
\text { S3 Gideceğim ülkenin siyasi politikasını incelerim ve turistlerin yasal korunma } \\
\text { haklarını okurum } \\
\text { S4 Eğer bir aracı şirket ile tatil programımı gerçekleştirmeye karar verdiysem o şirketin } \\
\text { eksizsiz olarak bütün lisanslarını ve sertifikalarını görmek isterim. }\end{array}$}} & \multicolumn{2}{|l|}{0.56} \\
\hline & & \multicolumn{2}{|l|}{0.67} \\
\hline & & \multicolumn{2}{|l|}{0.55} \\
\hline \multicolumn{2}{|r|}{ Açıklanan Varyans (\%) } & \multicolumn{2}{|c|}{59.974} \\
\hline & Total & \multicolumn{2}{|c|}{1.799} \\
\hline & Kaiser Mayer Olkin (KMO) test & \multicolumn{2}{|c|}{0.64} \\
\hline & Bartlett's Test of Sphericity & \multicolumn{2}{|c|}{45.815} \\
\hline & Ki-Kare & \multicolumn{2}{|c|}{3.829} \\
\hline & $\mathrm{X}^{2 / \mathrm{df}}$ & \multicolumn{2}{|c|}{1.915} \\
\hline & NFI & \multicolumn{2}{|c|}{0.92} \\
\hline & CFI & \multicolumn{2}{|c|}{0.96} \\
\hline & IFI & \multicolumn{2}{|c|}{0.96} \\
\hline & RMSEA & \multicolumn{2}{|c|}{0.09} \\
\hline Güvenirlik Analizi & Cronbach's Alpha & \multicolumn{2}{|c|}{0.89} \\
\hline
\end{tabular}

Tablo 6'da öğrencilerin cinsiyet değişkeni ile gençlik turizmin değişkenleri arasındaki ilişkiyi saptamak için korelasyon analizi yapılmıştır. Analiz sonucuna göre, cinsiyet ile Doğu Akdeniz ve Kocaeli Üniversitesi öğrencilerinin konaklama faktörü arasında $p=0.033, p<0.05$ değerinde anlamlı ilşkisi olduğu saptanmıştır. Ayrıca, cinsiyet ile Doğu Akdeniz ve Kocaeli Üniversitesi öğrencilerinin ulaşım faktörü arasında $\mathrm{p}=0.008, \mathrm{p}<0.01$ düzeyinde anlamlı bir ilişki içerisinde olduğu görülmektedir. Başka bir perspektiften bakıldığında, güven değişkeninin ortalama değerinin $X=3.69$ olduğu görülmektedir. Bunun anlamı, üniversite öğrencilerinin güven değişkeni sorularına katılma yönünde 
eğilim göstermiştir. Bunun aksine, ekonomi değişkeninin ortalama değerinin $X=3.34$ olduğunu görülmektedir. Öğrencilerin ekonomiye yönelik sorulan sorulara kararsız cevap verdiği anlaşılmaktadır.

Tablo 6. Değişkenlerin Ortalama ve Korelasyon Değeri

\begin{tabular}{lcccccc}
\hline & \multicolumn{7}{c}{ Korelasyon } \\
\hline & $\mathrm{X}$ & 1 & 2 & 3 & 4 & 5 \\
CINSIYYET & 1,4311 & 1 &, & & & \\
EKONOMI & 3,3452 &, 070 & 1 & & \\
KONAKLAMA & 3,4883 &, $127^{*}$ &, $597^{* *}$ & 1 & & \\
ULAŞIM & 3,6297 &, $157^{* *}$ &, $451^{* *}$ &, $485^{* *}$ & 1 & \\
GÜVEN & 3,6989 &, 089 &, $561^{* *}$ &, $633^{* *}$ &, $557^{* *}$ & 1 \\
\hline
\end{tabular}

Not: ${ }^{*} \mathrm{p}<0.05 ; * * \mathrm{p}<0.01$

Gençlik turizmi belirleyen ekonomi, konaklama, ulaşım ve güven değişkenleri ile cinsiyet arasında anlamlı bir fark olup olmadığını tespit etmek için çoklu regrasyon analizi uygulanmış olup sonuçları tablo 7'de gösterilmiştir. Bu analizin sonucunda, anketi yanıtlayanların cinsiyetleri ile öğrencilerin gençlik turizme bakış açısının bazı değişkenleri arasında arasında anlamlı fark gözlemlenirken, bazılarında ise anlamlı bir fark mevcut olmadığı görülmüştür. $R^{2}$ değeri bağımlı değişkendeki değişimin \% kaçının bağımsız değişken tarafından açılandığını ifade etmektedir (Dursun ve Kocagöz, 2010). Her 4 modelde sirasiyla $\mathrm{R}^{2}=0.02 ; 0.05 ; 0.03 ; 0.04$ olarak tespit edilmiştir. Bu değerler, öğrencilerin gençlik turizmi etkileyen etmenleri ile cinsiyet algılarının sırasıyla \%2; \%5; \%3; \% 4 'ü olduğunu açıklamaktadır. Tablo 7'de çoklu regrasyon analizinde dört model kullanılmıştır. Model 1'de öğrencilerin KKTC gençlik turizme bakışı ile cinsiyet arasında istatistiksel olarak anlamlı bir fark saptanmıştır $(\mathrm{F}(4,174)=1,183 ; \mathrm{p}>0,05)$. Bunun aksine, cinsiyet ile KKTC ulaşım arasında $\mathrm{t}=1.772$ değeri üzerinde \%10 düzeyinde anlamlı bir fark vardır. Model 2'de ise, Kocaelinde okuyan öğrencilerin gençlik turizme bakışı ile cinsiyet arasında istatistiksel olarak anlamlı bir fark saptanmıştır $(F(4,99)=1,474 ; p>0,05)$. Ancak, cinsiyet ile kocaeli güven değişkeni arasında $t=1.781$ değeri üzerinde \%10 düzeyinde anlamlı bir ilişki olduğu gözlemlenmiştir. Model 3'de cinsiyet ile hem KKTC hem de kocaelinde okuyan öğrencilerin gençlik turizme bakışı arasında F $(4,278)=2.129$ değerinde $\mathrm{p}>0,05$ düzeyinde anlamlı bir fark saptanmamıştır. Ancak, cinsiyet ile ulaşım arasında $\mathrm{t}=1.965$ değeri üzerinde $\mathrm{p}=0.05$ düzeyinde anlamlı bir fark olduğu anlaşılmaktadır. Son olarak, model 4 'de anketin yapıldığ $\mathrm{p}=0.05)$ ve güven ( $\mathrm{t}=-1.892 ; \mathrm{p}=0.06)$ arasında anlamlı bir ilişki olduğu regrasyon analizi neticesinde görülmektedir. 
Tablo 7. Çoklu Regrasyon Analizi

\begin{tabular}{|c|c|c|c|c|c|c|c|}
\hline Değişkenler & B & S.E & $\mathbf{t}$ & $\beta$ & $p$ & $\mathbf{F}$ & $\mathbf{R}^{2}$ \\
\hline \multicolumn{8}{|c|}{ Model 1: Bağımlı Değişken: } \\
\hline \multicolumn{8}{|l|}{ Cinsiyet } \\
\hline Sabit & 1.130 & 0.173 & $6.527^{*}$ & - & 0.000 & \multirow{5}{*}{1.183} & \multirow{5}{*}{0.026} \\
\hline KKTC Ekonomi & -0.075 & 0.061 & -1.220 & -0.124 & 0.224 & & \\
\hline KKTC Konaklama & 0.030 & 0.068 & 0.436 & 0.049 & 0.663 & & \\
\hline KKTC Ulaşım & 0.069 & 0.039 & $1.772^{* * *}$ & 0.167 & 0.078 & & \\
\hline KKTC Güven & -0.006 & 0.052 & -0.110 & -0.013 & 0.912 & & \\
\hline \multicolumn{8}{|c|}{ Model 2: Bağımlı Değişken: } \\
\hline \multicolumn{8}{|c|}{ Cinsiyet } \\
\hline Sabit & 1.443 & 0.484 & $2.984^{* *}$ & - & 0.004 & \multirow{5}{*}{1.474} & \multirow{5}{*}{0.056} \\
\hline Kocaeli Ekonomi & -0.148 & 0.113 & -1.305 & -0.145 & 0.195 & & \\
\hline Kocaeli Konaklama & 0.103 & 0.135 & 0.758 & 0.084 & 0.450 & & \\
\hline Kocaeli Ulaşım & -0.004 & 0.069 & -0.055 & -0.006 & 0.956 & & \\
\hline Kocaeli Güven & 0.140 & 0.078 & $1.781^{* * *}$ & 0.214 & 0.078 & & \\
\hline \multicolumn{8}{|c|}{ Model 3: Bağımlı Değişken: } \\
\hline \multicolumn{8}{|l|}{ Cinsiyet } \\
\hline Sabit & 1.014 & 0.196 & $5.173^{*}$ & - & 0.000 & \multirow{5}{*}{2.129} & \multirow{5}{*}{0.030} \\
\hline Ekonomi & -0.028 & 0.065 & -0.436 & -0.034 & 0.663 & & \\
\hline Konaklama & 0.086 & 0.072 & 1.189 & 0.099 & 0.236 & & \\
\hline Ulaşım & 0.080 & 0.041 & $1.965^{* * *}$ & 0.144 & 0.050 & & \\
\hline Güven & -0.022 & 0.052 & -0.415 & -0.035 & 0.679 & & \\
\hline \multicolumn{8}{|c|}{ Model 4: Anketin Yapıldığı Yer } \\
\hline Sabit & 0.850 & 0.190 & $4.482^{*}$ & - & 0.000 & \multirow{5}{*}{2.990} & \multirow{5}{*}{0.041} \\
\hline Ekonomi & 0.119 & 0.063 & $1.903^{* * *}$ & 0.147 & 0.058 & & \\
\hline Konaklama & 0.084 & 0.070 & 1.196 & 0.099 & 0.233 & & \\
\hline Ulaşım & 0.050 & 0.040 & 1.265 & 0.092 & 0.207 & & \\
\hline Güven & -0.096 & 0.051 & $-1.892^{* * *}$ & -0.159 & 0.060 & & \\
\hline
\end{tabular}

Not: ${ }^{*} \mathrm{p}<0.001 ; * * \mathrm{p}<0.05 ; * * * \mathrm{p}<0.10$

\section{TARTIŞMA VE SONUÇ}

Gençlik turizmi, bazı çalışmalarda 18-25 bazı çalışmalarda ise 15-24 yaşları arasında olan bireylerin aile yakınları olmadan tatil yapmaları ve seyahat etmeleri olarak tanımlanmaktadır (Polat, 2017). Yapılan çalışmalarda, genç bireylerin turistik faaliyetlere katılma eğilimi, diğer yaş gruplarından daha yüksek olması sebebiyle gençlik turizmi ortaya çıkmıştır (Yılmaz, 2018; Oral,1992). Genç nüfus, psikolojik özelliklerinden dolayı değişime açık ve maceracı bir kişiliğe sahiptir. Ayrıca, bazı genç grupların aile ile bağlarının çok sıkı olmaması ve sorumluluklarının az olması gençlerin konaklama 
yer seçiminde titiz davranmamaları da gençlerin seyahat etme eğilimlerini artmasına neden olmaktadır. Gençlik turizmini sosyal turizm olarak tabir edersek, Türkiye'de ve Kıbrıs'ta yaz aylarında yapılan yaz okulları hem eğitim hemde turizm açısından büyük önem taşımaktadır. Bu amaçlı öğrenci yurtlarının yaz programı için gelen öğrencilere açılması ve havayolları, demiyollarının belli dönemlerde öğrencilere yönelik uyguladıkları indirimler de gençlik turizmin sosyal turizmin kapsamında yer aldığını göstermektedir. Avrupa'da, genç nüfus seyahat pazarının ve konaklama faaaliyetinin en dinamik kesimini oluştumaktadır. Avrupa'da yaşayan genç birey hem iç turizm hem de diş turizm faaliyetlerine katılarak gençlik turizm kavramının öneminin artmasına olanak tanımaktadır (Acır, 2010; Polat, 2017). Gençlerin farklı şehirleri, tarihi ve en çok ilgilerini çekecek olan kültürleri tanıyabilmesi için kendilerine imkanlar sağlanmalıdır. Bu anlamda maddi güçlüklerden dolayı yaşamış oldukları şehirlerden çıkamayan gençlere teşvik veya burs programları düzenlenmelidir. Farklı okullar ile değişim prograları veya yaz okulları düzenlemelidir.

Globalleşen dünyamızda, hızla gelişmekte ve değişmekte olan turizm sektörü çok farklı ve özelleşmekte ve her tür turiste birçok imkan ve avantajı da beraberinde sunmaktadır. Yüzlerce çeşidi olan turizmin türlerinden olan gençlik turizmini daha iyi anlayabilmek ve gençlerin tercihlerini etkileyen faktörleri belirlemek için yapmış olduğumuz araştırmamızda, toplam 283 adet anket toplanmıştır. Anketi cevaplayan 179 Doğu Akdeniz Üniversitesi öğrencileri ile 104 Kocaeli Üniversitesi öğrencilerin görüşlerinden oluşan sonuçlar doğrultusunda, genç bireyler tatil programı yaparken ekonomik, konaklama, ulaşım ve güvenlik faktörlerinden dolaylı olarak etkilenmektedir. Kul'un (2014); p değerinin 0,10 ile 0,05 aralığında olması sınırda anlamlılık derecesini taşıdığı görüşü dikkate alındığından, cinsiyet değişkeni ile KKTC ulaşım arasında sınırda anlamlılık ilişkisine sahiptir. Aynı zamanda, cinsiyet ile Kocaeli güven arasında da sınırda anlamlılılık ilişkisi vardır. Diğer yandan, anketin yapıldığı yer ile, gençlik turizminin ekonomi ve güven faktörleri arasında sınırda anlamlılık ilişkisi analiz neticesinde görülmektedir.

Başka bir perspektiften bakıldığında, çalışmanın amacı, Doğu Akdeniz ve Kocaeli Üniversitesin de okuyan öğrencilerin tatil programı yaparken ki tutumlarını ekonomik, konaklama, ulaşım ve güvenlik faktörleri tercihlerini nasıl etkilemektedir sorusuna cevap aramaktı. Üniversite öğrencilerinin seyahat etmesini etkileyen birçok faktör vardır. Bu faktörlerin bazıları, gençlik turizmini olumsuz bir şekilde etkilemektedir. Örnek verecek olursak, vize, dil, güvenlik ve ulaşım problemleri, kur farklılıkları ve ucuz otel bulamama gibi sorunlar gençlik turizmine bakışı etkileyen problemlerin başında yer almaktadır. Araştırmanın sonuçları dikkate alındığında, Doğu Akdeniz ve Kocaeli Üniversitesin'de okuyan gençlerin, gençlik turizme bakışını ekonomik, ulaşım, konaklama ve güvenlik unsurları doğrudan veya dolaylı olarak etkilediği görülmüştür.

Yapılan bu çalışma sonucunda, araştırmaya katılan bireylerin cevapları doğrultusunda gençlik turizmi sorunlarına yönelik çeşitli öneriler getirilmiştir. Öncelikle, genç bireylere toplu taşıma ve havayolu şirketlerinin önemli oranda indirim yapılması, gidilecek yerlerdeki müzelerin öğrencilere ücretsiz olması gibi çözüm önerileri genç turistlerin ekonomik anlamda turizme katılımı sağlamasında önemli bir destek olabilmektedir. Bunun yanında, ülkede dil eğitimi kalitesinin artırılması ve yabancı dil eğitiminin iyileştirilmesi genç bireyler farklı bir dile sahip olacağından dil problemleri ortadan kalkacaktır. Bu bağlamda, genç bireyler, yurtdışına çıkmarken dil korkusu yaşamayacaklardır. Seyahat etmiş bireylerden başka, ülke ile ilgili bilgiler alması ve onların tecrübelerinden faydalanması kültürel ve sosyal anlamda korkularının azalmasına neden olacaktır. Genç bireyler hem farklı kültürleri tanımak ve merak ettikleri yerleri görmek ve daha fazla bilgi sahibi olmak için sorular sorma fırsatı yakalamak düşüncesi onların seyahat etme isteklerini 
artıracaktır. Üniversitelerdeki değişim programları ve yaz okulları gençlerin farklı ülkeler ve kültürler tanımasına çok büyük katkılar koyacaktır. Dolayısıyla yaz okullarına geren önem verilmeli ve yurtiçindeki öğrenciler ve yazokulu için gelen öğrencilerle iletişim kurulması arkadaş ortamı yaratılması için aktiviteler düzenlenmelidir. Son olarak, otellerin erken rezervasyon ve son dakika fırsatları gibi uygun bir fiyata mal olmasını sağlayacak uygulamalar genç bireylerin seyahat etme tercihlerini etkileyecek önemli bir husus olacaktır. Dolayısıyla, gençlere bunların duyurlması ve farkındalıklarının artırılması için çalışmalar yapılmalı gerekirse email veya reklam mesajı olarak gönderilmelidir.

Araştırmada bazı sınırlılıklar vardır. İlk olarak, bu çalışma sadece Kocaeli ili ve Kuzey Kıbrıs Türk Cumhuriyeti'nin Gazimağusa şehindeki üniversitede yürütülmesi önemli bir sinırlılık olarak kabul edilebilir. Çalışmanın sonuçlarının genelleştirebilmesi için daha büyük kitleler üzerinde uygulanması ve bölgedeki farklı üniversiteler üzerinde araştırmalar yapılması gelecek çalişmalar için önemli bir unsur olarak karşımıza çıkmaktadır. Araştırma konusu bakımından üniversite öğrencilerinin, gençlik turizmine bakışı ve tutumlarnın demografik değişkenlerle ilişkisinin tam olarak tespit edilememesi de önemli bir sınırlılığını oluşturmaktadır. Yabancı kaynaklar da gençlik turizmi hakkında çalışmalar mevcut iken, türkçe literatürde çalışmaların hemen hemen hiç yok denecek kadar az olması dikkat çekmektedir. Bu nedenle, genç turistlerin seyahat esnasında ve sonrasında beklentilerinin tespit edilmesi, demoğrafik değişkenlerin ve gençlik turizm faktörlerinin genç turistlerin bakışını etkisinin kapsamlı tespitleri yapılabilmesi açısından bu çalışma ileride yapılması planlanan çalışmalara öncülük edecektir.

\section{KAYNAKÇA}

Acır, E. (2010, Ekim). Türkiye'de Gençlik Turizmi Potansiyelinin Geliştirilmesi ve Çözüm Önerileri. Ankara: T.C. Kültür ve Turizm Bakanlığı Yatırım ve İşletmeler Genel Müdürlüğü.

Akinci, Z. ve Kasalak, M. A. (2016). Sürdürülebilir Turizm Yönetimi Açisindan Özel İlgi Turizminin Yeri ve Önemi. Çatalhöyük Uluslararası Turizm ve Sosyal Araştırmalar Dergisi, 1(1), 161-182.

Albayrak, A. ve Özmen, Ö. N. T. (2018). Turizm Gelişimi İle Kültürel Kimlik Olgusu Arasindaki İlişki: Alaçati Örneği. Dokuz Eylül Üniversitesi İşletme Fakültesi Dergisi, 19(1), 129-150.

Bahar, E. (2016). Gençlik Turizminin Sorunları, Gelişmesine Yönelik Çözüm Önerileri, İstanbul Arel Üniversitesi İIBF Ekonomi, Yönetim ve Sosyal Araştırmalar Dergisi, 1(1), 45-58.

Bell, C. (2002). The big 'OE' Young New Zealand travellers as secular pilgrims. Tourist Studies, 2(2), 143-158.

Beşirli, H. (2010). Yemek, Kültür ve Kimlik. Milli Folklor, 22(87), 159-169.

Bizirgianni, I. and Dionysopoulou, P. (2013). The influence of tourist trends of youth tourism through social media (SM) \& information and communication technologies (ICTs). Procedia-Social and Behavioral Sciences, 73, 652-660.

Carr, N. (2002). The Tourism-Leisure Behavioural Continuum. Annals of Tourism Research, 29(4), 972986. 
Doğan, N. ve Başokçu, T. O. (2010). İstatistik Tutum Ölçeği İçin Uygulanan Faktör Analizi ve Aşamalı Kümeleme Analizi Sonuçlarının Karşılaştırılması. Eğitimde ve Psikolojide Ölçme ve Değerlendirme Dergisi, 1(2), 65-71.

Duran, E. (2011). Turizm, Kültür ve Kimlik İlişkisi; Turizmde Toplumsal Ve Kültürel Kimliğin Sürdürülebilirliği. İstanbul Ticaret Üniversitesi Sosyal Bilimler Dergisi, 10(19), 291-313.

Dursun, Y. ve Kocagöz, E. (2010). Yapisal Eşitlik Modellemesi ve Regresyon: Karşilaştirmali Bir Analiz. Erciyes Üniversitesi İktisadi ve İdari Bilimler Fakültesi Dergisi, (35), 1-17.

Eryılmaz, B. ve Zengin, B. (2014). Sosyal Medyada Konaklama Işletmelerine Yönelik Tüketici Yaklaşımları Üzerine Bir Araştırma. İşletme Bilimi Dergisi, 2(1), 147-167.

Ghețe, A. M. (2015). The Importance of Youth Tourism. Annals of The University of Oradea, Economic Science Series, 24(2), 688-694.

Gülbahar, O. (2009). Turizmin Bölgelerarasi Gelişmişlik Farklarini Gidermedeki Rolü (Türkiye Örneği). Atatürk Üniversitesi İktisadi ve İdari Bilimler Dergisi, 23(1), 19-47.

Gürbüz, A. (2002). Turizmin Sosyal Çevreye Etkisi Üzerine Bir Araştirma. Teknoloji Dergisi, (1-2), 4959.

Han, H., Kim, W. and Kiatkawsin, K. (2017). Emerging Youth Tourism: Fostering Young Travelers' Conservation Intentions. Journal of Travel \& Tourism Marketing, 34(7), 905-918.

Horak, S. and Weber, S. (2000). Youth Tourism in Europe: Problems and Prospects, Tourism Recreation Research, 25(3): 37-44.

Kaşlı M, Arslaner E, Demirci B., Yılmazdoğan., O. (2013). Gençlerin Turistik Tercihlerinin Belirlenmesi: Eskişehir'de Yaşayan Gençler Örneği. 14. Ulusal Turizm Kongresi Bildiriler Kitabı, ss. 928-940.

Kaya, M. ve Kaya, M. F. (2013). Sürdürülebilir Kalkinmaya Yönelik Tutum Ölçeği Geliştirme Çalişmasi. Marmara Coğrafya Dergisi, (28), 175-193.

Khoshpakyants, A. V. and Vidishcheva, E. V. (2010). Challenges of Youth Tourism. European Researcher, 1(1), 101-103.

Kılıç, B. ve Kurnaz, A. (2010). Alternatif Turizm ve Ürün Çeşitliliği Oluşturmada Ekolojik Çiftlikler: Pastoral Vadi Örneği. İşletme Araştırmaları Dergisi, 2(4), 39-56.

Kozak, M. A., Evren, S., Çakır, O. (2013). Tarihsel Süreç Içinde Turizm Paradigması. Anatolia: Turizm Araştırmaları Dergisi, 24(1), 7-22.

Kozak, N., Kozak, M. A., Kozak, M. (2015). Gençlik Turizmi. N. Kozak, M. A. Kozak ve M. Kozak İçinde, Genel Turizm İlkeler - Kavramlar (S. 21-47). Ankara: Detay Yayıncılık.

Köroğlu A. ve Güleç B (2008). Gençlik Turizmi. İçinde Turistik Ürün Çeşitlendirmesi. (Ed. N. Hacıoğlu ve C. Avcıkurt). Ankara: Nobel Yayın-Dağıtım.

Kul, S. (2014). Istatistik Sonuçlarinin Yorumu: P Degeri ve Güven Araligi Nedir? /Interpretation of Statistical Results: What Is P Value and Confidence Interval? Plevra Bülteni, 8(1), 11. 
Küçükaltan, G. (1995) Gençlik Turizmi Önemi Dünyada ve Türkiye'deki Gelişme Seyri. Yayınlanmamış Doktora Tezi. İstanbul Üniversitesi Sosyal Bilimler Enstitüsü, İstanbul.

TURSAB (2015). 20 Ağustos 2019 tarihinde https://www.tursab.org.tr/haberler/tursab-genclikturizmi-2015-raporu_11776 adresinden erişilmiştir.

Oral, S. (1992). Türkiye'de Gençlik Turizmi ve Geliştirilmesi (Sorunlar-Öneriler). Gençlik Turizmi Konferansı. Ankara: Turizm Bakanlı̆̆ı, 125-134.

Özdemir, M. ve Kervankiran, İ. (2011). Turizm ve Turizmin Etkileri Konusunda Yerel Halkin Yaklaşimlarinin Belirlenmesi: Afyonkarahisar Örneği. Marmara Coğrafya Dergisi, (24), 1-25.

Öztürk, Y. ve Yazıcıoğlu, İ. (2002). Gelişmekte Olan Ülkeler İçin Alternatif Turizm Faaliyetleri Üzerine Teorik Bir Çalışma. Gazi Üniversitesi Ticaret ve Turizm Eğitim Fakültesi Dergisi, 2 (183-195).

Polat, E. (2017). Genç Bireylerin Turistik Tercihlerin Belirlenmesi Üzerine Balıkesir Kent Merkezinde Bir Araştırma. International Journal of Cultural and Social Studies, 3(2), 235-248

Richards G. and Wilson J (2006). Youth and Adventure Tourism. In Tourism Business Frontiers, Consumers, Products and Industry. (Eds. D. Buhalis ve C. Costa). UK: Elsevier.

Sellars, A. (1998). The Influence of Dance Music on The UK Youth Tourism Market. Tourism Management, 19(6), 611-615.

Smith, V. L. (1992). Tourism Alternatives: Potentials And Problems In The Development of Tourism. Philadelphia: University of Pennsylvania Press.

Şahin, G. ve Dinçer, İ., F. (2016). Gençlik Turizmi Sorunlarının Analizi ve Çözüm Önerileri 15. Geleneksel Turizm Sempozyumu Bildiri Kitabı S.215, 2016, Balıkesir Üniversitesi Turizm Fakültesi 22 Nisan 2016, Balıkesir.

Tezcan, N. Ş., Zengin, B., Kıngır, S. (2018). Gençlerin Turizm Algısı ve Turizme Verdikleri Destek; Sakarya Üniversitesi Öğrencileri Üzerine Bir Araştırma. Bartın Üniversitesi İktisadi ve İdari Bilimler Fakültesi Dergisi, 9(18), 147-168.

Tümertekin, E. ve Özgüç, N. (2011). Beşeri Coğrafya: İnsan, Kültür, Mekân (12. Baskı). İstanbul: Çantay Kitabevi.

Uygur, S. M., ve Baykan, E. (2007). Kültür Turizmi ve Turizmin Kültürel Varliklar Üzerindeki Etkileri. Ticaret Ve Turizm Egitim Fakültesi Dergisi, Sayi, 2, 30-49.

Yılmaz, G. (2018). Üniversite Gençliğinin Turizme Bakış Açısı: İstanbul Arel Üniversitesi Örneği. OPUS-Uluslararası Toplum Araştırmaları Dergisi, 8(15), 1516-1538.

Yildiz, S. ve Yildiz, Z. (2015). Bilişim Teknolojilerinin Turizm Pazarlaması, Dağıtım Sistemi ve Seyahat Acentelerinin İş Modeli Değişimine Etkisi. İnsan ve Toplum Bilimleri Araştırmaları Dergisi, 4(3), 595-611.

Zoğal, V. ve Emekli, G. (2017). Yaratici Turizme Kavramsal ve Coğrafi Bir Yaklaşim. Ege Coğrafya Dergisi, 26(1), 21-34. 